\title{
The Effect of Employee Performance on Consumer Satisfaction at Setia Hotel, Puruk Cahu, Murung Raya
}

\author{
Rinto Alexandro ${ }^{*}$, Tonich Uda ${ }^{2}$, Fendy Hariatama H. ${ }^{3}$, Uci Lestari ${ }^{4}$
}

1,2,3,4 Prodi Pendidikan Ekonomi, Fakultas Keguruan dan Ilmu Pendidikan, Universitas Palangka Raya, Indonesia

\section{ART I CLE IN F O}

\section{Article history:}

Received July 20, 2021

Revised July 23, 2021

Accepted August 11, 2021

Available online August 25, 2021

Keywords:

Employee Performance,

Become a Consumer,

Hotel

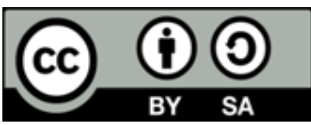

This is an open access article under the CC BY-SA license.

Copyright $(2021$ by Author. Published by Universitas Pendidikan Ganesha.

\begin{abstract}
A B S T R A C T
Employee performance basically has a big influence on the company's contribution in terms of the quality of service provided to consumers. Employee performance is one of the main assets that must be owned by the company, especially the hotel business where the aim is to measure customer satisfaction. Quality performance will create comfort and satisfaction for consumers. But the fact is that often the problem in the field is the opposite. This study aims to analyze the influence of employee performance on customer satisfaction at Hotel Setia Puruk Cahu Murung Raya. The type and research approach used is quantitative research, with data collection techniques through: Observation, Interview, and Questionnaire/Questionnaire. Data analysis techniques: Simple Linear Regression Test, Hypothesis Test ( $t$ test) and Determination Test (R Square test). From the results of the analysis that the researchers did, it can be concluded that the variable "Employee Performance $(\mathrm{Y})$ has a positive influence on the variable "Consumer Satisfaction" (X) where in a simple linear regression test it is found that every additional unit of Employee Performance Variable will increase satisfaction. Consumers are 0.441 or $44.1 \%$, and the t test shows that the influence of employee performance on customer satisfaction at Hotel Setia Puruk Cahu Murung Raya is very significant where the significant value is 0.001 which means Ho is rejected and Ha is accepted, then the influence of employee performance is also classified as high on consumer satisfaction, which is equal to 0.614 or $61.4 \%$.
\end{abstract}

\section{INTRODUCTION}

The hotel business is very promising, this encourages many entrepreneurs to open a hotel service business. The hotel business which is engaged in lodging accommodation has been growing and there are more and more hotel buildings in every city, both in big cities and in small cities (Pramono, 2016; Zhao \& Zhou, 2020). For a long time, the hotel business is considered a profitable business and is always developing. However, to maximize comfort both for the company in terms of pursuing profits and for consumers to get satisfaction from the services provided by employees, so researchers feel this research needs to be done. In addition, previous research has also shown good results to be used as a reference for entrepreneurs to develop and advance their business by paying attention to the performance of their employees to provide satisfaction to consumers (Hadiwijaya, 2018; Insyroh et al., 2018). The results show that the communication and service quality variables have a positive and significant influence on the performance of the Bhayangkara Palembang Nurse Hospital. The communication variable has a more dominant influence on the performance of the Bhayangkara Palembang Nurse Hospital in the comparison of service quality variables. Furthermore, service quality, product and price have a positive and significant effect on customer satisfaction (Insyroh et al., 2018; Petricia \& Syahputra, 2015). Every company in running a business certainly cannot be separated from efforts to achieve the planned goals (Virgiawansyah et al., 2016; Wardhana et al., 2017). The success or failure of a company in achieving these goals is influenced by the ability of management to see current and future opportunities and opportunities.

Performance is a term derived from the word job performance or actual performance, namely (work achievement or actual achievement achieved by someone), employee performance is the result of work (output) both quality and quantity achieved by an employee per unit of time (Kusuma \& Ardana, 2014; Mangkunegara, 2015). Performance is basically what employees do or don't do that affects the company's contribution, including the quality services provided. Job improvement strategy is a company's way to 
improve employee performance in order to achieve company goals (Pramulaso, 2020; Widodo, 2014). In order for the work improvement strategy to be successful, the company needs to know the performance targets. Performance targets that are set are specific individuals, in all areas of projects, processes, routine activities will be the responsibility of employees (Mangkunegara, 2015). If performance goals are grown from within the employee will form a self-strength and if the work environment situation also promotes it, it will be easier to achieve the desired performance. Improving company performance can be achieved through increasing human resources owned by hotel managers (Rahayu \& Saryanti, 2014). Human resources are needed by companies because they are one of the important assets that help companies to achieve goals, human resource management essentially plays a role in recruiting, screening, training, rewarding and evaluating. In addition, HR management as a strategy in implementing management functions, namely planning, organizing, leading and controlling in every activity of the organization (Joo \& Lee, 2017; Masri \& Jaaron, 2017). Human resources in question are hotel human resources, namely a person or group of people who are involved in the operational activities of a hotel who play a role in the effort to produce and create products / services to meet the needs of hotel customers.

Hotel developments also occurred in the Murung Raya Puruk Cahu district, new hotels sprung up in Puruk Cahu and compete with each other to offer various facilities, quality, services and other advantages to provide added value to the services they offer. Hotel Setia is one of the hotels in Puruk Cahu Murung Raya, which provides a wide range of facilities, quality and services. Because this hotel business is a business that not only sells products but also sells services, apart from paying attention to product quality, they also pay attention to the performance of their employees, especially in serving hotel consumers. One of the ways this hotel is to create customer satisfaction is by implementing 6 components of employee performance assessment, consisting of work quality, quantity of work, punctuality, effectiveness, independence, and work commitment. The purpose of the first employee performance appraisal, namely the quality of work, is to review the quality of each employee in carrying out their duties which include suitability, neatness and completeness. The suitability in question is that employees must adhere to the work plan set by the hotel with predetermined goals or objectives, while neatness is the accuracy of employees both in serving every complaint and consumer request as well as in doing other work such as cleaning rooms, providing breakfast, as well as in welcoming consumers, and furthermore neatness where employees are required to always pay attention to appearance with the aim that consumers do not feel uncomfortable and disturbed by the appearance of employees.

The purpose of the second assessment, which is the quantity of work, is that employees are required to provide the same service to all consumers without discriminating, because if consumers are treated equally then no consumer will feel disadvantaged and this can also provide satisfaction for consumers. Next is punctuality, where employees are required to be disciplined, the meaning of the word discipline here is that employees must arrive at the hotel before working hours start, employees must always maintain the cleanliness of the hotel room so that if there are consumers who want to stay, they don't have to wait long, because this can reduce The mood and sense of customer satisfaction with the service at the hotel, the punctuality of employees in providing breakfast for consumers and the responsiveness of employees in serving any complaints and consumer requests are also important. Effectiveness means that employees must work optimally in responding to every complaint and consumer request, and they must also try their best to serve consumers to avoid fatal mistakes that might damage the mood of consumers, because consumers will tend to be dissatisfied with the employee's performance and ultimately can reduce their interest to stay at the hotel again. Independence means that employees are required to be independent in doing their respective jobs, because it can cause work delays if an employee is too dependent on his colleagues which may eventually make consumers have to wait a long time, this can also affect customer satisfaction. Work commitment means that employees must be able to work in accordance with the work commitments they agreed with the hotel, and employees are also required to carry out their responsibilities, especially in serving consumers.

\section{METHODS}

The design of this research begins with a quantitative problem and limits the problems in the problem formulation. The formulation of the problem is stated in the question sentence, then the researcher uses the theory to answer it. Rresearch design has to be specific, clear and detailed, determined steadily from the start, as a guide step by step (Sugiyono, 2014). The research design links the variables X and Y variables. This study consists of two variables, namely the independent variable (X) namely employee performance and the variable $(\mathrm{Y})$ namely customer satisfaction. This research was conducted at the Setia Puruk Hotel Cahu Murung Raya, the population in this study were all consumers who stayed at the Setia Puruk Hotel Cahu Murung Raya in June 2019 to be exact, totaling 430 consumers. The sample in this study 
was the consumers who stayed at the loyal Puruk Cahu Murung Raya hotel in June 2019 as many as 43 people, namely $10 \%$ of the 430 consumers. Setia Hotel is one of so many hotels in Puruk Cahu City, Murung Raya Regency, Central Kalimantan Province. Located at Jalan Jenderal Sudirman No. 211 Puruk Cahu which was established on 7 March 2010 by Mr. H. Barlin. This hotel is in a strategic location in Puruk Cahu City and this hotel is very attentive to the convenience of its consumers. The hotel manager wishes every guest who stays at this hotel to feel safe and comfortable, so that guests will have more confidence to always choose this hotel.

Initially, Setia Hotel only had a capacity of 25 rooms, now this hotel has grown and increased its capacity to 31 rooms. There are two choices of rooms, king type with single bed and twin type with twin beds. Each room is furnished with modern minimalist interiors and exteriors as well as other supporting facilities to increase the comfort of visitors to stay at Hotel Setia. Some rooms are also renovated to be more spacious with a capacity of between 2 to 3 people. This hotel is now no longer just a place to stay but also offers a meeting place and even recreation. Now Setia Hotel has 12 employees which shown in Table 1.

Table 1. List of Setia Hotel Employees

\begin{tabular}{|c|c|c|}
\hline No & Position & Total \\
\hline 1. & Manager & 1 \\
\hline 2. & Receptionist & 2 \\
\hline 3. & Cook & 2 \\
\hline 4. & Security & 2 \\
\hline 5. & Cleaning Service & 5 \\
\hline & $\begin{array}{r}\text { Total } \\
\end{array}$ & 12 \\
\hline
\end{tabular}

This hotel will also provide a $10 \%$ discount for a minimum order of 10 rooms of all types, in addition, a $10 \%$ discount is also provided for each guest who stays for at least 5 consecutive days. This strategy is one of the hotel's marketing policies to retain its customers to face increasingly fierce competition.

\section{RESULTS AND DISCUSSIONS}

\section{Results}

Validity Test Results

Instrument The results of the distribution of the Pre-test Questionnaire were tested for validity and reliability. The validity test in this study uses the SPSS 16 program with the Pearson correlation method, which is to test the validity of each indicator item in the form of a statement. In general, validity is said to be the strength of conclusions, inferences, or propositions that are close to the truth of the results of research that is tired of being done. A scale is declared valid if the emerging scale is used to measure what should be measured and the resulting inference is close to the standard.

Table 2. Research Instrument Validity Analysis

\begin{tabular}{cccc}
\hline No Item & rxy & Rtable $\mathbf{5 \%}$ (43) & Description \\
\hline 1 & 0.421 & 0.294 & Valid \\
2 & 0.404 & 0.294 & Valid \\
3 & 0.343 & 0.294 & Valid \\
4 & 0.491 & 0.294 & Valid \\
5 & 0.700 & 0.294 & Valid \\
6 & 0.359 & 0.294 & Valid \\
7 & 0.347 & 0.294 & Valid \\
8 & 0.535 & 0.294 & Valid \\
9 & 0.438 & 0.294 & Valid \\
10 & 0.349 & 0.294 & Valid \\
11 & 0.439 & 0.294 & Valid \\
12 & 0.595 & 0.294 & Valid \\
13 & 0.645 & 0.294 & Valid \\
14 & 0.661 & 0.294 & Valid \\
\hline 15 & 0.550 & 0.294 & Valid \\
\hline
\end{tabular}


The results of the validity test in Table 2 state that all indicators in the pretest, statements on the employee performance variable and also on the consumer satisfaction variable are valid. Invalid items do not correlate with other statements, so they can be omitted or corrected. Therefore, as many as 15 statements that can be used in research because all of them are declared valid.

\section{Instrument Reliability Test Results}

The reliability test in this study was carried out using the SPSS 16 program with Cronbach's alpha reliability method. This method is used to determine whether the instrument is reliable or not, using a certain limit of 0.05 . Reliability less than 0.05 is not good, while 0.06 is acceptable and above 0.07 is good (Sekaran, 2003). The reliable construct will then be used as a construct in the actual research. The calculation of this reliability test is carried out after conducting a validity test and reducing invalid indicators. The results of the reliability test can be seen in Table 3. The table shows that each variable has a high reliability value, which is greater than 0.05 . Thus, the two variables can be used in research.

Table 3. Research Variable Reliability

\begin{tabular}{ccc}
\hline No & Variables & Cronbach's Alpha \\
\hline 1. & Employee performance & 0,671 \\
2. & Consumer Satisfaction & 0,774 \\
\hline
\end{tabular}

\section{Employee Performance Variables}

Employee performance variables are measured in 6 dimensions, namely work quantity, work quality, timeliness, effectiveness, independence, and work commitment. Table 4 shows the respondents' answers are described by means of a frequency distribution table for each indicator.

Table 4. Respondents Answer on Employee Performance Variables

\begin{tabular}{|c|c|c|c|}
\hline Indicators & \begin{tabular}{|c|} 
Categories \\
\end{tabular} & Frequency & Percentage (\%) \\
\hline \multirow{6}{*}{$\begin{array}{l}\text { Work Quantity } \\
\text { Setia Hotel employees } \\
\text { are able to maintain } \\
\text { hotel cleanliness and } \\
\text { tidiness daily }\end{array}$} & Strongly Disagree (STS) & 0 & 0 \\
\hline & Disagree (TS) & 0 & 0 \\
\hline & Uncertain (R) & 0 & 0 \\
\hline & Agree (S) & 36 & 83,7 \\
\hline & Strongly Agree (SS) & 7 & 16,3 \\
\hline & $\begin{array}{r}\text { TOTAL } \\
\end{array}$ & 43 & 100 \\
\hline \multirow{6}{*}{$\begin{array}{l}\text { Work Quality } \\
\text { Setia Hotel Employees } \\
\text { always respond well to } \\
\text { every consumer } \\
\text { complaint }\end{array}$} & Strongly Disagree (STS) & 0 & 0 \\
\hline & Disagree (TS) & 0 & 0 \\
\hline & Uncertain (R) & 0 & 0 \\
\hline & Agree (S) a & 37 & 86 \\
\hline & Strongly Agree (SS) & 6 & 14 \\
\hline & $\begin{array}{r}\text { TOTAL } \\
\end{array}$ & 43 & 100 \\
\hline \multirow{6}{*}{$\begin{array}{l}\text { Work Quality } \\
\text { Setia Hotel Employees } \\
\text { never make mistakes } \\
\text { when } \\
\text { customers }\end{array}$} & Strongly Disagree (STS) & 0 & 0 \\
\hline & Disagree (TS) & 0 & 0 \\
\hline & Uncertain (R) & 2 & 4,6 \\
\hline & Agree (S) & 34 & 79,1 \\
\hline & Strongly Agree (SS) & 7 & 16,3 \\
\hline & $\begin{array}{r}\text { TOTAL } \\
\end{array}$ & 43 & 100 \\
\hline Punctuality & Strongly Disagree (STS) & 0 & 0 \\
\hline Setia Hotel Employees & Disagree (TS) & 0 & 0 \\
\hline are always on time in & Uncertain (R) & 15 & 34,9 \\
\hline serving breakfast every & Agree (S) & 26 & 60,5 \\
\hline \multirow[t]{2}{*}{ morning } & Strongly Agree (SS) & 2 & 4,5 \\
\hline & $\begin{array}{r}\text { TOTAL } \\
\end{array}$ & 43 & 100 \\
\hline Punctuality & Strongly Disagree (STS) & 0 & 0 \\
\hline Setia Hotel employees & Disagree (TS) & 0 & 0 \\
\hline are always on time in & Uncertain (R) & 21 & 48,8 \\
\hline cleaning rooms & Agree $(S)$ & 22 & 51,2 \\
\hline \multirow[t]{2}{*}{ according to schedule } & Strongly Disagree (SS) & 0 & 0 \\
\hline & \begin{tabular}{|c|} 
TOTAL \\
\end{tabular} & 43 & 100 \\
\hline
\end{tabular}




\begin{tabular}{|c|c|c|c|}
\hline Indicators & Categories & Frequency & Percentage (\%) \\
\hline Effectiveness & Strongly Disagree (STS) & 0 & 0 \\
\hline Setia Hotel Employees & Disagree (TS) & 0 & 0 \\
\hline provide services that & Uncertain (R) & 14 & 48,8 \\
\hline meet consumer & Agree $(\mathrm{S})$ & 23 & 51,2 \\
\hline \multirow[t]{2}{*}{ expectations } & Strongly Agree (SS) & 6 & 0 \\
\hline & $\begin{array}{r}\text { TOTAL } \\
\end{array}$ & 43 & 100 \\
\hline \multirow{7}{*}{$\begin{array}{l}\text { Independence } \\
\text { Setia Hotel Employees } \\
\text { are able to complete } \\
\text { their } \\
\text { responsibilities }\end{array}$} & Strongly Disagree (STS) & 0 & 0 \\
\hline & Disagree (TS) & 0 & 0 \\
\hline & Uncertain (R) & 3 & 7 \\
\hline & Agree $(S)$ & 40 & 93 \\
\hline & Strongly Agree (SS) & 0 & 0 \\
\hline & TOTAL & 43 & 100 \\
\hline & Strongly Disagree (STS) & 0 & 0 \\
\hline \multirow{5}{*}{$\begin{array}{l}\text { Commitment } \\
\text { Setia Hotel Employees } \\
\text { have provided services } \\
\text { as promised }\end{array}$} & Disagree (TS) & 0 & 0 \\
\hline & Uncertain (R) & 9 & 21 \\
\hline & Agree (S) & 32 & 74,4 \\
\hline & Strongly Agree (SS) & 2 & 4,6 \\
\hline & $\begin{array}{r}\text { TOTAL } \\
\end{array}$ & 43 & 100 \\
\hline
\end{tabular}

Table 4 indicates that: First, the majority of respondents agree that Setia Hotel employees are able to maintain the cleanliness and tidiness of the hotel every day, so that it can create a sense of comfort for consumers as well as create a sense of satisfaction for hotel consumers. Respondents who answered strongly agree are respondents who are very confident in the quality of employee performance at Setia Hotel because these consumers have seen from the cleanliness and tidiness of the hotel, they are always maintained every day, and employees also always maintain the cleanliness of the hotel. Second, the majority of respondents agree that employees always handle every consumer complaint properly, this can also create a sense of satisfaction because consumers feel safe and comfortable with hotel services. And for consumers who answered strongly agree, it means that consumers are very confident in the performance of employees and consumers feel that hotel employees are very good at handling each of their complaints.

Third, the majority of respondents agree that the service at Setia Hotel is good and satisfying or in accordance with consumer expectations. Respondents who choose strongly agree were respondents who strongly believed in the quality of service provided at Setia Hotel, and respondents who chose Uncertain were consumers who were still unsure whether Setia Hotel's services were in line with what they expected or not. Fourth, the majority of respondents agree that hotel employees are always on time in serving breakfast every morning for hotel consumers, for respondents who answer strongly agree are respondents who are very confident in the quality of service of Setia Hotel employees because consumers feel that employees are on time in providing breakfast, And for consumers who answered Uncertain, these consumers have not been able to provide a definite assessment of employee performance, especially the discipline of hotel employees.

Fifth, the majority of respondents agree that hotel employees are always punctual in cleaning hotel rooms according to the hotel schedule, and for consumers who answered Uncertain, they have not been able to assess or give a definite assessment of the discipline performance or timeliness of employees in cleaning rooms at the hotel. Sixth, the majority of respondents agree that Setia Hotel employees provide services in accordance with consumer expectations so that they are satisfied with the services provided by hotel employees, for respondents who answered strongly agree were respondents who strongly believed in the quality of employee performance in serving hotel customers because they are satisfied if the service is as expected, and for consumers who answer uncertain, they have not been able to provide an assessment of the suitability of the existing service with their expectations.

Seventh, the majority of respondents agree that hotel consumers believe that Setia Hotel employees are not dependent on others because hotel employees are able to do their respective duties well, and for consumers who choose uncertain, these consumers have not been able to rate or provide an assessment of whether or not there is an additional charge at the hotel. Eighth, the majority of respondents agree that Setia Hotel employees have provided services in accordance with what was promised by the hotel, for respondents who answered strongly agree were respondents who strongly believed in the quality of employee performance in serving consumers because they felt satisfied if the existing services were in accordance with with those promised by the hotel, and for consumers who choose uncertain, they have not been able to provide an assessment of the suitability of the existing services with those promised by the hotel. 


\section{Consumer Satisfaction Variable}

Consumer Satisfaction variable is measured in 5 dimensions, namely, Quality of Service, Emotional, Price, and Cost. Table 5 shows the respondents' answers are described by means of a frequency distribution table for each indicator.

Table 5. Respondents Answer on Consumer Satisfaction Variables

\begin{tabular}{|c|c|c|c|}
\hline Indicators & $\begin{array}{c}\text { Categories } \\
\end{array}$ & Frequency & Percentage (\%) \\
\hline Product Quality & Strongly Disagree (STS) & 2 & 4,7 \\
\hline The products and & Disagree (TS) & 2 & 4,7 \\
\hline services provided by & Uncertain (R) & 1 & 2,3 \\
\hline Setia Hotel are in & Agree $(S)$ & 35 & 81,3 \\
\hline \multirow{2}{*}{$\begin{array}{l}\text { accordance with what } \\
\text { consumers expect }\end{array}$} & Strongly Agree (SS) & 3 & 7 \\
\hline & TOTAL & 43 & 100 \\
\hline Product Quality & Strongly Disagree (STS) & 0 & 0 \\
\hline The facilities at the & Disagree (TS) & 0 & 0 \\
\hline Setia Hotel have & Uncertain (R) & 15 & 34,9 \\
\hline provided a sense of & Agree (S) & 21 & 48,8 \\
\hline \multirow[t]{3}{*}{ security and comfort } & Strongly Agree (SS) & 7 & 16,3 \\
\hline & TOTAL & 43 & 100 \\
\hline & Strongly Disagree (STS) & 0 & 0 \\
\hline \multirow{5}{*}{$\begin{array}{l}\text { Service Quality } \\
\text { Service at Setia Hotel is } \\
\text { Very Satisfactory }\end{array}$} & Disagree (TS) & 0 & 0 \\
\hline & Uncertain (R) & 1 & 2,3 \\
\hline & Agree (S) & 12 & 27,9 \\
\hline & Strongly Agree (SS) & 30 & 69,8 \\
\hline & TOTAL & 43 & 100 \\
\hline \multirow{6}{*}{$\begin{array}{l}\text { Emotion } \\
\text { The Products and } \\
\text { Services Provided At } \\
\text { Setia Hotel are Very } \\
\text { Satisfactory }\end{array}$} & Strongly Disagree (STS) & 1 & 2,3 \\
\hline & Agree (TS) & 1 & 2,3 \\
\hline & Uncertain (R) & 1 & 2,3 \\
\hline & Agree (S) & 21 & 48,9 \\
\hline & Strongly Agree (SS) & 19 & 44,2 \\
\hline & TOTAL & 43 & 100 \\
\hline \multirow{6}{*}{$\begin{array}{l}\text { Price } \\
\text { The Rates Offered Are } \\
\text { Relatively Affordable }\end{array}$} & Strongly Disagree (STS) & 0 & 0 \\
\hline & Disagree (TS) & 0 & 0 \\
\hline & Uncertain (R) & 18 & 41,9 \\
\hline & Agree (S) & 18 & 41,9 \\
\hline & Strongly Agree (SS) & 7 & 16,2 \\
\hline & TOTAL & 43 & 100 \\
\hline \multirow{6}{*}{$\begin{array}{l}\text { Price } \\
\text { The price offered is in } \\
\text { accordance with the } \\
\text { quality of the product } \\
\text { or service provided }\end{array}$} & Strongly Disagree (STS) & 0 & 0 \\
\hline & Tidak Setuju (TS) & 0 & 0 \\
\hline & Uncertain (R) & 22 & 51,2 \\
\hline & Agree (S) & 15 & 34,9 \\
\hline & Strongly Agree (SS) & 6 & 13,9 \\
\hline & TOTAL & 43 & 100 \\
\hline \multirow{6}{*}{$\begin{array}{l}\text { Fees } \\
\text { There are no additional } \\
\text { costs other than the } \\
\text { products or services } \\
\text { provided }\end{array}$} & Strongly Disagree (STS) & 1 & 2,3 \\
\hline & Disagree (TS) & 2 & 4,7 \\
\hline & Uncertain (R) & 5 & 11,6 \\
\hline & Agree $(S)$ & 27 & 62,8 \\
\hline & Strongly Agree (SS) & 8 & 18,6 \\
\hline & TOTAL & 43 & 100 \\
\hline
\end{tabular}

Table 5 shows that: First, the majority of respondents agree that the products and services provided by the hotel are in accordance with what is expected by consumers, so they can feel satisfied because it is in accordance with their expectations, respondents who answered strongly agree were respondents who were very confident and satisfied with the quality of the products and services they receive. The respondents who chose to be in doubt are those who have not been able to provide an assessment of the quality of the products or services provided by the hotel, for consumers who choose the answer to disagree means that the consumer is not satisfied and does not find a match between expectations 
and reality, and consumers Those who choose strongly disagree are those who feel that the products and services at the hotel are not in line with what consumers expect.

Second, the majority of respondents agree that the facilities provided at the Setia Hotel have provided a sense of security and comfort for consumers, and consumers who answered strongly agree mean that consumers are very confident in the safety and comfort of the Setia Hotel. Respondents who answered Uncertain were consumers who still could not give a definite assessment of the sense of security and comfort provided by the hotel. Third, the majority of respondents strongly Agree, strongly believe in the quality of service that is Setia Hotel, for respondents who agree that the service at the hotel is loyal and can be satisfactory or in accordance with consumer expectations and respondents who answered Uncertain are consumers who still haven't found conformity between expectations and reality or the services at the hotel are not in accordance with what consumers expect.

Fourth, the majority of respondents agree that the products and services provided at Setia Hotel are appropriate and can create a sense of satisfaction or satisfaction for consumers. Respondents who answered strongly agree were respondents who strongly believed in the quality of products and services at the hotel and also felt that the existing products and services were very satisfying for consumers. And for consumers who answered in doubt, these consumers have not been able to assess or provide an assessment of the products or services they receive from the Setia Hotel, even some who respond strongly disagree and also disagree. Fifth, the majority of respondents agree that the price offered is relatively cheap according to the consumer's wallet, there are even some who respond strongly agree and for consumers who answer in doubt also make up the majority of respondents, these consumers have not been able to assess or provide an assessment of the tariffs offered by the hotel.

Sixth, the majority of respondents chose Uncertain which indicates that these consumers have not been able to provide an assessment of the suitability of the prices offered with the products or services they receive from Setia Hotel. Respondents who answered strongly agree were respondents who strongly believed in the quality of existing products and services that were in accordance with the price offered and for consumers who answered agreed that the price offered was in accordance with the quality obtained, both the products and services provided were in accordance with the offered price. Seventh, the majority of respondents agree that the hotel does not charge additional fees or it can be said that the hotel does not provide facilities or products that make consumers pay additional fees, and for consumers who answer uncertain, they have not been able to provide an assessment of whether or not there are additional fees. In addition, there are some consumers who disagree and some even strongly disagree, but consumers who strongly agree are more than those who disagree.

\section{Simple Linear Regression Test Results}

Table 6. Results of Coefficients Regression Analysis

\begin{tabular}{lccccc}
\hline \multirow{2}{*}{ Model } & \multicolumn{2}{c}{$\begin{array}{c}\text { Unstandardized } \\
\text { Coefficients }\end{array}$} & $\begin{array}{c}\text { Standardized } \\
\text { Coefficients }\end{array}$ & \multirow{2}{*}{ T } & \multirow{2}{*}{ Sig. } \\
\cline { 2 - 4 } & B & Std. Error & Beta & & \\
\hline $1 \quad$ (Constant) & 3.936 & 6.091 & & 6.064 & .001 \\
Employee Performance & .441 & .102 & .560 & 4.328 & .001 \\
\hline
\end{tabular}

Based on Table 6, it can be understood that: Constant $a=3.936$ and coefficient $b=0.441$ so that the simple regression equation becomes $\mathrm{Y}=3.936+0.441$ constant a of 3.936 indicates that if employee performance is zero $(X=0)$, then the customer satisfaction score of 3,936 units. The regression coefficient for $\mathrm{X}$ is 3.936 which states that each addition of one unit of $\mathrm{X}$ variable will increase customer satisfaction by 0.441 or by $44.1 \%$, the coefficient is positive, meaning that there is a positive influence between employee performance on customer satisfaction.

\section{Hypothesis Test Results}

Hypothesis testing ( $t$ test) in Table 6, the $t$ count on employee performance is 4,328 at degrees of freedom ( $\mathrm{df}$ ) $=\mathrm{N}-2=43-2=41$, then the $t$ table is determined to be 1.217 . So it can be concluded that $t$ count $>t$ table $(4,328>1,217)$. From the results of the $t$ test, the significant value is less than $0.05(0.001 \mathrm{t}$ table, then Ho is declared rejected and Ha is accepted, meaning that the independent variable has a significant influence on the dependent variable, on the contrary if $t$ count $<t$ table then Ho is declared accepted and Ha is rejected, meaning that the independent variable does not have a significant effect on the dependent variable. Hypothesis testing ( $t$ test) is generally used to test the significance of a variable, the following will explain the partial performance variable testing: employee performance variables which include 6 performance appraisal indicators according to Robbins (2006:260) include work quality, work quantity, 
timeliness, the effectiveness of independence, and work commitment where the results of the t-test indicate that the $t$-count value of the employee's performance is 4.328 and the $t$-table value is determined at 1.217 . It can be concluded that $t$ count $>t$ table $(4,328>1.217)$. From the results of the $t$ test, the significant value is less than 0.05 (0.001) which means that there is a significant effect of employee performance variables which include 6 performance appraisal indicators according to Robbins (2006:260) which include work quality, work quantity, timeliness, effectiveness independence, and work commitment with customer satisfaction.

\section{Determination Test Results (R square)}

The coefficient of determination ( $R$ square) aims to determine how much influence the independent variable of employee performance has on the dependent variable of consumer satisfaction. Based on the data analysis, it is known that the $\mathrm{R}$ square value is $0.614(61,4 \%)$. This shows that by using the regression model, the independent variable, namely employee performance, has an effect on the dependent variable of consumer satisfaction by 61" $4 \%$. According to Dominikus Dolet Unaradjan 2005: 202, To provide an interpretation of the coefficient of determination $\left(\mathrm{R}^{2}\right)$ which are found to be large or small and are consulted with the table of interpretation of the $r$ values. From the results of data analysis, it can be stated that this proves the effect of employee performance on customer satisfaction of 0.614 or $61.4 \%$ and the value of the influence is high or in accordance with the coefficient interval above, if the coefficient interval value is $0.60-0.799$ then categorized into strong category. So the influence of employee performance on consumer satisfaction of 0.614 or $61.4 \%$ is classified as strong, while the remaining $38.6 \%$ is explained by other unknown factors or variables and not included in this regression analysis.

\section{Discussion}

In general, the results of this study are very satisfactory, the results of the analysis show that the performance of Setia Hotel employees is very good. This can be shown from the performance variable which has a positive influence on increasing consumer satisfaction which is classified as high. The results showed that employee performance variables with 6 performance appraisal indicators which include work quality, work quantity, timeliness, independence effectiveness, and work commitment have a positive influence in increasing customer satisfaction by 0.441 or $44,1 \%$ (Sachro \& Pudjiastuti, 2013). This proves that the quality of work from employee performance shown by providing good service to each customer can increase customer satisfaction. The quantity of work shown by providing comfort and a sense of security to every consumer can also increase customer satisfaction, the timeliness of employee performance as shown by providing services and responding to consumer complaints quickly or on time can also increase customer satisfaction, the effectiveness of employee performance as shown by provide maximum service and try to minimize the possibility of fatal errors, independence from employee performance is shown to provide good service in accordance with their work functions, work commitment from employee performance shown by being responsible for customer satisfaction.

The results of this study have similarities with the results of previous relevant studies where in general the good performance given by each employee in providing services to consumers ultimately gives satisfaction to consumers and the company benefits from this. From research explains that the performance dimension greatly influences consumer satisfaction (Loekito et al., 2017). This is what certainly becomes material for entrepreneurs to evaluate the performance and services provided to consumers in order to achieve company goals. Employee performance has an indirect effect on consumer satisfaction (Maliki, 2015). Furthermore, employee performance in providing services is the key to success in being able to satisfy consumers because through company employees they can interact with customers (Nursiti, 2019). The results of previous research conclude that all hypotheses are accepted, service quality and employee performance partially and simultaneously have a positive and significant effect on customer satisfaction variables (Dintyani et al., 2017). Employee performance has a positive and significant influence on consumer satisfaction (Desfandriyani, 2018). The customer is a person's feeling when what is obtained (service) is in accordance with what is expected (Sulistyowati \& Sinaga, 2018). The results of this research are that simultaneously and partially service quality and employee performance have a significant influence on community satisfaction (Pramulaso, 2020). Collectively the same Service Performance and Customer Satisfaction have a significant effect on the Loyalty of Depositors of Bank Mandiri Samarinda Branch (Wardhana et al., 2017). From the results of the another previous study, it shows that partially and simultaneously have a positive and significant effect on customer satisfaction (Alfi \& Nur, 2017). The results obtained in this study are that e-service quality has a positive and significant effect on e-satisfaction on the Tokopedia site (Anita, 2018).

That is the result of research conducted by various researchers that the author uses as a reference, which basically gives the same results that will have a good influence on consumer or community 
satisfaction. And there are still several other studies conducted by researchers with the same results. Such as Product Quality and Service Quality on Customer Satisfaction (Inka et al., 2014). The Impact of Service Quality on Customer Satisfaction (Valdo \& Silvya, 2014). Service Quality Towards Sharia Pawnshop Customer Satisfaction (Wirdayani, 2017). Service Quality Towards Customer Satisfaction (Khoirista, 2015). Bukalapak.Com Service Quality Towards Consumer Satisfaction With the Webqual 4.0 Method (Fauziah \& Wulandari, 2018). Leadership Style, Motivation, and Work Discipline on Employee Performance (Sudarmo. et al., 2016). Work Environment and Work Discipline and Work Motivation on Employee Performance (Hidayat \& Taufiq, 2012). Motivation, Discipline, and Satisfaction Influence on Employee Performance (Sajangbati, 2013). Consumer Satisfaction Mediates Price on Consumer Loyalty in Shopping (Darmawan \& Ekawati, 2017). Service Quality, Customer Relations and Company Image on Loyalty Through Customer Satisfaction (Rahayu \& Saryanti, 2014). The Effect of Service Quality to Customer Satisfaction and Customer Loyalty (Sachro \& Pudjiastuti, 2013). Service Quality and Corporate Image on Customer Satisfaction and Customer Service Center Loyalty (Safitri et al., 2018). Product Quality and Service Quality on Customer Satisfaction in Forming Customer Loyalty (Embiring et al., 2014). Service Quality, Brand Image and Their Influence on Customer Satisfaction and Customer Loyalty (Sondakh, 2014). Service Quality on Customer Loyalty with Customer Satisfaction as the Intervening variable (Jimanto et al., 2014). Service Quality and Price Fairness Towards Consumer Satisfaction (Krisnanda \& Rastini., 2018).

\section{CONCLUSION}

Employee Performance has a positive influence on the variable Consumer Satisfactionwhere in the Linear Regression test Simple, it can be seen that each additional unit of Employee Performance Variable will increase Consumer Satisfaction by 0.441 or $44.1 \%$, and from the $t$ test it also indicates that the effect of Employee Performance on Customer Satisfaction at Hotel Setia Puruk Cahu Murung Raya is very significant where the significance value is 0.001 which means Ho is rejected and Ha is accepted, then the influence of employee performance is also high on consumer satisfaction, which is 0.614 or $61.4 \%$. With this research, which gives the result that employee performance is very influential on consumer satisfaction, managers and related business owners can pay more attention to this. So that some suggestions will be put forward by researchers for the progress of the company in carrying out its business routines. After processing, analyzing, and interpreting the collected data, the authors would like to propose some suggestions for Setia Hotel Puruk Cahu to improve service quality in order to create a higher level of customer satisfaction, such as: Setia Hotel Puruk Cahu Murung Raya needs to conduct regular and continuous surveys to find out the level of satisfaction of the consumers who stay there and to know more about the wishes of the consumers so that the addition of those wishes can quickly be anticipated by the hotel and will make fulfilling customer needs easier and more satisfying which in the end maintain consumer loyalty. The hotel can also conduct a survey on the quality of services available at hotels and especially hotels in the Puruk Cahu area as well as hotels outside the Puruk Cahu area that are considered good, and can apply it at Setia Hotel to improve the service quality of Setia Hotel. The Setia Hotel Puruk Cahu is also advised to provide souvenirs or gifts for loyal customers who stay there, at least those who have stayed more than 2 consecutive days.

\section{REFERENCES}

Alfi, S. L., \& Nur, R. A. (2017). Pengaruh Kualitas Pelayanan (Service Quality) Terhadap Kepuasan Pelanggan PT. Sucofindo Batam. Journal of Business Administration, 1(2), 232-243. https://jurnal.polibatam.ac.id/index.php/JABA/article/view/619.

Anita. (2018). Pengaruh E - Service Quality Terhadap E- satisfaction pada Pengguna Di Situs Tokopedia. Jurnal Agora, 6(1), 1-10. http://publication.petra.ac.id/index.php/manajemen-bisnis/article/ view/6459.

Darmawan, P., \& Ekawati, N. W. (2017). Pengaruh Kepuasan Konsumen Memediasi Harga Terhadap Loyalitas Konsumen Dalam Berbelanja Pada Florist Online di Denpasar. E-Jurnal Manajemen Unud, 6(4), 2076-2104. https://ojs.unud.ac.id/index.php/Manajemen/article/view/27970.

Desfandriyani, D. (2018). Pengaruh Kinerja Karyawan Dan Kualitas Pelayanan Konsumen Terhadap Kepuasan Konsumen Pro Chicken (Studi Kasus Di Pro Chicken Purworejo). Jurnal Pendidikan Ekonomi, 7(1), 59-66. http://ejournal.umpwr.ac.id/index.php/oikonomia/article/view/5358.

Dintyani, Putri, R., \& Maskan, M. (2017). Pengaruh Kualitas Pelayanan Dan Kinerja Karyawan Terhadap Kepuasan Konsumen Di Jawa Timur Park 1, Batu - Jawa Timur. Jurnal Aplikasi Bisnis, 3(1). http://jab.polinema.ac.id/index.php/jab/article/view/81.

Embiring, I. J., Suharyono., \& Kusumawati, A. (2014). Pengaruh Kualitas Produk dan Kualitas Pelayanan terhadap Kepuasan Pelanggan dalam Membentuk Loyalitas Pelanggan (Studi pada Pelanggan 
McDonald's MT. Haryono Malang). Jurnal Administrasi Bisnis, 15(10). http://administrasibisnis.studentjournal.ub.ac.id/index.php/jab/article/view/607.

Fauziah, D. N., \& Wulandari, D. A. N. (2018). Pengukuran Kualitas Layanan Bukalapak.Com Terhadap Kepuasan Konsumen Dengan Metode Webqual 4.0. Jurnal Ilmu Pengetahuan Dan Teknologi Komputer, $\quad 3(2), \quad$ 173-180. $\quad$ http://ejournal.nusamandiri.ac.id/ejurnal/ index.php/jitk/article/view/569/401.

Hadiwijaya, H. (2018). Pengaruh Komunikasi Dan Kualitas Pelayanan Terhadap Kinerja Perawat Di Rumah Sakit Bhayangkara Palembang. Jurnal Internasional Ilmu Sosial Dan Bisnis, 2(3), 124-131. https://ejournal.undiksha.ac.id/index.php/IJSSB/article/view/14142.

Hidayat, Z., \& Taufiq, M. (2012). Pengaruh Lingkungan Kerja dan Disiplin Kerja serta Motivasi Kerja Terhadap Kinerja Karyawan Perusahaan Daerah Air Minum (PDAM) Kabupaten Lumajang. Jurnal WIGA, 2(1). https://ejournal.stiewidyagamalumajang.ac.id/index.php/wiga/article/view/64.

Inka, J., Suharyono., \& Andriani, K. (2014). Pengaruh Kualitas Produk dan Kualitas Pelayanan Terhadap Kepuasan Pelanggan Dalam Membentuk Loyalitas Pelanggan (Studi pada Pelanggan McDonald's MT.Haryono Malang). Jurnal Administrasi Bisnis, 15(1), 1-10. https://media.neliti.com/media/ publications/84504-ID-pengaruh-kualitas-produk-dan-kualitas-pe.pdf.

Insyroh, W., Setyowati, T., \& Santoso, B. (2018). Determinan Kualitas Pelayanan, Harga dan Produk Terhadap Kepuasan Pelanggan Telkomsel Flash Di Bondowoso. Jurnal Internasional Ilmu Sosial Dan Bisnis, 2(3), 132-140. https://ejournal.undiksha.ac.id/index.php/ IJSSB/article/view/16212.

Jimanto, Budiono, R., \& Yohanes, S. K. (2014). Pengaruh Service Quality terhadap Loyalitas Pelanggan dengan Customer Satisfaction sebagai variabel Intervening pada ritel bioskop the premiere surabaya. Jurnal Manajemen Pemasaran Petra, 2(1). https://media.neliti.com/ media/publications/132877-ID-pengaruh-service-quality-terhadap-loyali.pdf.

Joo, B. K., \& Lee, I. (2017). Workplace happiness: work engagement, career satisfaction, and subjective wellbeing. Evidence-Based HRM, 5(2), 206-221. https://doi.org/10.1108/EBHRM-04-2015-0011.

Khoirista, A. (2015). Pengaruh Kualitas Pelayanan Terhadap Kepuasan Pelanggan (Survey Pada Pelanggan Fedex Express Surabaya). Jurnal Administrasi Bisnis, 25(2). http://administrasibisnis.studentjournal.ub.ac.id/index.php/jab/article/view/1000.

Krisnanda, A. B., \& Rastini., N. M. (2018). Pengaruh Service Quality Dan Kewajaran Harga Terhadap Kepuasan Konsumen Warung Mina Di Kota Denpasar. Jurnal Manajemen, 7(9). https://ojs.unud.ac.id/index.php/Manajemen/article/view/38626.

Kusuma, I. P. S. W., \& Ardana, K. (2014). Pengaruh Penempatan dan Kompensasi Terhadap Kepuasan Kerja dan Kinerja Karyawan. E-Jurnal Manajemen, $7(3)$. https://ocs.unud.ac.id/index.php/Manajemen/article/view/8286.

Loekito, Rahadiyarsi., A., \& Hukama, L. D. (2017). Pengaruh Kualitas Pelayanan Terhadap Kepuasan Konsumen Laboratorium Klinik (Studi Kasus Laboratorium Klinik X Jakarta). Jurnal Internasional Ilmu Sosial Dan Bisnis, 1(4), 256-270. https://ejournal.undiksha.ac.id/index.php/ IJSSB/article/view/12533.

Maliki, M. U. (2015). Pengaruh Kinerja Karyawan Terhadap Kepuasan Konsumen Dengan Kompensasi Sebagai Variabel Intervening Pada Tenant - Tenant Di Palembang ICON. Jurnal Manajemen, 3(4). https://jurnal.unpal.ac.id/index.php/jm/article/view/236.

Mangkunegara, A. A. . (2015). Manajemen Sumber Daya Manusia Perusahaan (12th ed.). Pt Remaja Rosdakarya.

Masri, H. A., \& Jaaron, A. A. M. (2017). Assessing green human resources management practices in Palestinian manufacturing context: An empirical study. Journal of Cleaner Production, 143, 474489. https://doi.org/10.1016/j.jclepro.2016.12.087.

Nursiti, D. (2019). Pengaruh Kinerja Karyawan Terhadap Kepuasan Dan Loyalitas Pelanggan Chatime. Jurnal Psychomutiara, 2(1). http://e-journal.sari-mutiara.ac.id/index.php/Psikologi/article/view.

Petricia, D., \& Syahputra. (2015). Pengaruh Kualitas Produk, Harga, Promosi dan Kualitas Pelayanan terhadap Proses Keputusan Pembelian (Studi pada Konsumen Kopi Progo Bandung). Eproceeding of Management, 2(2), 2117-2124.

Pramono, J. (2016). The Process of Environmental Management at Star Rated Hotel in Bali. In Tourism \& Sustainable Regional Development In Indonesia. (pp. 20-32). Unpad Press.

Pramulaso, E. Y. (2020). Kualitas Pelayanan dan Kinerja Pegawai terhadap Kepuasan Masyarakat di Unit Pelayanan Terpadu Satu Atap Kementerian Ketenagakerjaan. Jurnal Ekonomi \& Manajemen Universitas Bina Sarana Informatika, 18(1). https://ejournal.bsi.ac.id/ejurnal/index.php/perspektif /article/download/7549/3853.

Rahayu, B. S., \& Saryanti, E. (2014). Pengaruh Kualitas Pelayanan, Hubungan Pelanggan dan Citra Perusahaan terhadap Loyalitas Melalui Kepuasan Nasabah. Jurnal Advance, 1(2). https://www.e- 
journal.stie-aub.ac.id/index.php/advance/article/view/31/0.

Sachro, \& Pudjiastuti, S. R. (2013). The Effect Service Quality to Customer Satisfaction and Customer Loyalty of Argo Bromo Anggrek Train Jakarta-Surabaya in Indonesia. Journal of Business and Management, 12(1). http://www.iosrjournals.org/iosr-jbm/papers/Vol12-issue1/E01213338.pdf.

Safitri, E., Rahayu., \& Indrawati, N. K. (2018). Pengaruh Kualitas Pelayanan dan Citra Perusahaan terhadap Kepuasan Pelanggan dan Loyalitas Pelanggan Service Center (Studi pada Pelanggan Samsung Service Center di Kota Malang). Jurnal Ekonomi Bisnis, 21(1). http://journal.um.ac.id/index.php/ekobis/article/view/7446.

Sajangbati, I. (2013). Motivasi, Disiplin, Dan Kepuasan Pengaruhnya Terhadap Kinerja Pegawai PT. Pos Indonesia (Persero) Cabang Bitung. Jurnal EMBA, 1(4). https://ejournal.unsrat.ac.id/index.php/emba/article/view/2750\%0A\%0A.

Sekaran, U. (2003). Research methods for business: A skill-building approach. (4th editio). John Wiley \& Sons, Inc.

Sondakh, C. (2014). 'Kualitas Layanan, Citra Merek dan Pengaruhnya terhadap Kepuasan Nasabah dan Loyalitas Nasabah Tabungan (Studi pada Nasabah Taplus BNI Cabang Manado). Jurnal Riset Bisnis Dan Manajemen, 3(1). https://ejournal.unsrat.ac.id/index.php/jrbm/article/view/7525.

Sudarmo., Swasti., \& Hendika, L. (2016). Pengaruh Gaya Kepemimpinan, Motivasi, dan Displin Kerja terhadap Kinerja Karyawan PT. Empat Enam Jaya Abadi Balikpapan. Jurnal Sains Terapan, 1(2), 4855. https://jurnal.poltekba.ac.id/index.php/jst/article/view/115.

Sugiyono. (2014). Metode Penelitian Pendidikan Pendekatan Kuantitatif, Kualitatif, dan R\&D. Alfabeta.

Sulistyowati, I., \& Sinaga, M. (2018). Pengaruh Kinerja Karyawan Terhadap Konsumen (Studi Pengendalian Mutu D'Ayam Crispy di Yogyakarta). IDEAS, 5(6). https://ideas.repec.org/p/osf/osfxxx/ fy5s6.html.

Valdo, J. U., \& Silvya, L. M. (2014). Analisis Kualitas Jasa Layanan pengaruhnya Terhadap Kepuasan Nasabah Pada PT. Pegadaian (Persero) Cabang Teling. Jurnal Riset Ekonomi, Manajemen, Bisnis Dan $\begin{array}{lll}\text { Akuntansi } & \text { (EMBA), } & \text { 654-663) }\end{array}$ https://ejournal.unsrat.ac.id/index.php/emba/article/view/5630.

Virgiawansyah, E., Utomo, B. B., \& Rosyid, R. (2016). Pengaruh Kinerja Karyawan Terhadap Kepuasan Konsumen. Jurnal Pendidikan Dan Pembelajaran Khatulistiwa, 6(5). https://jurnal.untan.ac.id/index.php/jpdpb/article/view/15636/13743.

Wardhana, A. A., Hudayah., S., \& Wahyuni, S. (2017). Analisis Kinerja Layanan dan Pelanggan terhadap Loyalitas Nasabah Tabungan. Jurnal Manajemen, 9(1). http://journal.feb.unmul.ac.id/index.php/JURNALMANAJEMEN/article/view/2390.

Widodo, W. (2014). Upaya Peningkatan Kinerja Inovatif berbasis Pola Kerja Cerdas dalam Konteks Teknologi Informasi. Jurnal Manajemen Teknologi, 13(2), 154-172. https://doi.org/10.12695/jmt.2014.13.2.3.

Wirdayani, W. (2017). Pengaruh Kualitas Pelayanan Terhadap Kepuasan Nasabah Pegadaian Syariah Di Kota Pekanbaru. Jurnal Lembaga Keuangan Dan Perbankan, 2(1), 28-41. https://journal.febi.uinib.ac.id/index.php/almasraf/article/view/89.

Zhao, H., \& Zhou, Q. (2020). Socially responsible human resource management and hotel employee organizational citizenship behavior for the environment: A social cognitive perspective. International Journal of Hospitality Management, $\quad{ }_{x x x x,} 102749$. https://doi.org/10.1016/j.ijhm.2020.102749. 